\title{
R.P.F.の製造と炎の課題*
}

株式会社 関商店 関 勝 四 郎

\section{Production of RPF and Problems to Be Solved}

Katsushiro Seki

Seki Co.

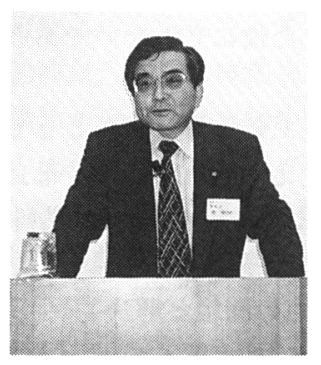

RPF is a pelletized product, which consists of waste paper and plastics, and is used as fuel for boilers. We are producing 3,500 tons every month at our 4 plants in two mills.

We started to develop this RPF thirteen years ago, aiming to utilize waste laminated paper products which were incinerated or disposed without any return.

The problem in general is that the business of utilizing waste materials is not free and is regulated with various laws relating to industrial waste handling. Our business was approved as a first case supported by a new energy development law in last December. We think it a meaningful step forward.

\section{R.P.F.開発経緯}

\section{1 開発の動機}

私の会社は, 13 年ほど前までは, 鉄スクラップ及 び製紙原料を扱う地方問屋をやっていた。鉄スクラッ プ及び製紙原料合わせて, 月間 3,500 トン近くの量を 扱っていたのであるが, 何分, この鉄スクラップ及び 製紙原料はないへん物価の優等生であり, 相場の変動 も大変なものであった。相場の変動が激しく, また, 不況期が長いという状況があり, 安定した経営がなか なかできないいう本当に困惑した時代が続いた。

特に第一次石油ショック終息後の古紙暴落の時には 笑えない話であるが，4トントラックに 8 トンほど山 積みして売上げが 1 台 2 万 4,000 円ぐらいで, キロ当 たり 3 円ぐらいであったが, それから禁忌品を全部は ねるための処理料が 2 万円ほど取られ, 結局, 残った のが 4,000 円。いろいろ人を使い苦労をしたのである

*第 5 回環境セミナー講演
が, 経営の方が一向に安定しないという感じを強く致 した時代である。

13 年ほど前, 産業古紙を扱う中でラミネート紙と いう新種の紙に出会い, これをなんとか製紙原料に使 つていただけないものか，方々の製紙会社を当たっり， いろいろ折衝したのであるが, 禁忌品ということで 1 社も使っていただけなかったということを経験した。 仕方なく, そのラミネート紙は焼却や埋め立てに回し まして処分していたのであるが，見れば見るほど綺麗 なもので，埋め立てや烤却に回すのが全く勿体ないと 思われ，これをなんとか有効利用できないものかとい うことを考えたのが R.P.F. 開発の動機となった。 また,この開発が成功すれば, 当社としても新たなビ ジネスを展開できるのではないか, 経営にも良い影響 をもたらすのではないかということで一生晒命考えた 次第である。

\section{2 開発の推進}

新技術の開発の順序として, まず最初に，一体何を 作ればこのラミネート紙あるいは古紙・廃プラスチッ 
ク類が最も有効な利用法になるだろうという考えから スタートした。いろいろ試行錯誤を行った。リサイク ルというのは，単純にものを作ってみてもその製品が 売れなければそのシステムの機能をすぐに失なうと言 う問題がある。しかも，製紙業界の種々の開発による 紙の高級化とともに複合紙及びラミネート紙等の廃棄 物は飛躍的に増えていくだろうという予測もあって, 1,000 トン単位あるいは 1 万トン単位で捌くことが出 来る規模のシステムでなければ有効性は認められない であろうし，また役に立たないであろうという思いを 持った。

いろいろ考えた結論が，燃料として利用し，それを エネルギーに変えて活用するのが最良の方法と決断す るに至る。そこで, 13 年前から燃料化技術の開発に 邁進することになった。

\section{3 開発時点の問題と解決}

燃料製造プラントに関しては, 当時のいろいろメー カーがあったが, 減容機メーカーの設備を燃料の製造 に転用してみようという思いがあったので，四国を始 め全国のいろいろのメーカーの減容機を実地に見て歩 いた。また, 燃料に関しては大阪のボイラーメーカー に相談し, 燃料として利用していくにはどのような品 質まで持って行くべきかを双方で研究してみた。

燃料として利用して貫うためには, 熱量及び形状が 一定していること，定量供給ができること，そして塩 素含有物は徽底的に排除するというのが最低の条件で あるということが分かり，3 年間ほど，その集荷シス テムの研究と燃料製造技術の研究，また燃焼性の特性 等のいろいろな実験を行った。例えば，いろいろな原 料の組合せによる固形化実験, いろいろな燃焼方式の ボイラーの燃焼実験等を繰り返し, 昭和 63 年, 流動 焼ボイラーがその当時では燃焼方式としては最適と判 断するに至り，それに適合する燃料のサイズおよび品 質を我が社ながらに決めて燃料供給先の確保に向かっ た。

\section{4 受 注 活動}

受注活動を藯命に行ったのが平成元年の秋。幸いに も栃木県足利市にある染色会社が今まで使って来た重 油ボイラーの更新で流動焼ボイラーが建設されること になり，その燃料としてR.P.F.を供給する契約の 運びになった。この新ボイラーと歩調を合わせ, R.P.F.の製造工場を群馬県の館林市に建設すること した。

\section{5 受注後の経緯}

平成 3 年の 7 月, R.P.F. 製造工場が竣工し, 試運 転と試験操業を 3 ケ月間行い, 平成 3 年の 10 月から
本格的に R.P.F. 生産に入った。そして平成 6 年に は旧来の製品はハンドリング性の問題があったため石 灰会社向けにペレット状の R.P.F.を作る生産技術 を開発し，館林工場を增設するとともに，埼玉県の属 宮町にある私どもの埼玉工場に 2 基のプラントを導入 し, 現在, 月間 3,500 トンの R.P.F.を順調に生産し, 供給するところまでになった。

ここでR.P.F.とR.D.Fの違いを若干申し上げて おきたい。あくまでも R.P.F.は産業古紙及び産業 から出る廃プラスチックを利用し, 徹底的な選別を行 ったものを原料に使用している。これに対して, R.D.F.は一般ゴミということで全てをただまとめ上 げるという形で固形にしたもので，品質面においても， 燃料特性においても大幅な差がある。それがR.P.F. とR.D.F.の端的な違いであることを概念としてご 理解いただきたいと思う。

\section{R.P.F の製造工程}

\section{1 原料集荷・選別・配送のシステム化}

R.P.F の製造に関し，まず原料の集荷, 選別, 配 送のシステム化に関して重要なことは, 燃料として流 通させるためには均質な熱量と均等な形状が要求され るということ, また最も重要なことは塩素分を一切含 有しないということである。塩素を一切含まないとい うのはちょっと無理ではあるが, ともかく塩素は含有 しない燃料でなければならないということが絶对的な 条件となっている。熱量は古紙とハイプラの混合の比 率を調整することにより均一化は可能である。また, 形状の方はプラントを調節することにより，一定の形 状のものが製造できる。

しかしながら, 塩素含有物の排除が一番の問題点で ある。この問題を解決するために，私どもでは R.P.F. 原料はイコール廃萧物であるが, 産業廃呆 物の選別・配送・製造を全て私どもで一貫して行うシ ステムを構築した。すなわち，まず原料の選別におい ては排出先企業に徹底した選別体制を構築していただ くということを要請し，また私どもから指導員を派遣 し，現場での選別・仕分けをお願いして歩いた。また， 集荷・配送の方も私どもが行い，ほかの産業廃棄物が 一切混入しないような方策をとった。また，それだけ 選別した原料をさらに燃料製造前に再チェックする二 重, 三重のチェック体制を敷き, 塩素分 $0.1 \%$ 以下と いう原料の集荷に成功した次第である。こうした努力 により, 燃料として品質を完全なものとし, ボイラー の塩素による腐食問題, あるいは現在, たいへんに問 題になっているダイオキシンの問題等の解決を容易に 
したところである。

足利市にある流動焼ボイラーに関しても, すでに十 数年前に完成したときにダイオキシンの発生のチェッ クは行っており, 現在の基準を 10 年前から満たして いるというボイラーの燃焼形態で実施し，たいへん高 い評価を得ている。

\section{2 生産工程}

次に生産工程について, 図 1 に生産フローを示す。 まず原料であるが，私どもが名前を出していいかど うかわかりませんが, 大日本印刷，あるいは凸版印刷 等大手印刷会社，あるいは東芝，日立といった大手電 機メーカーから，まず選別していただいた原料をプレ 又梱包して当社の館林工場あるいは埼玉工場に搬入し ている。それらの原料を開梱し, 四のエプロンコンベ アーに梱包の紐を解いただけの原料を投入する。

ついで，エプロンコンベアーから入った原料は，ま ず第 1 番目に破砕機に入る。この破砕機に関しまして は, 私どもが館林工場の第 1 号機を作る時点ではフィ ルム及び薄い紙等をいっぺんに大きなべイラー品から 4 センチメートル角まで粉砕できる破砕機はなかった ので，それゆえ，1号機ではまず 2 軸の破砕機で大ば らしし，ついでハンマーシュレッダーで50ミリ角に するという2 段破砕方式をとった。しかし，2 号機目 からの破砕機は，ベイラー品ごと入れ，ここに出てく

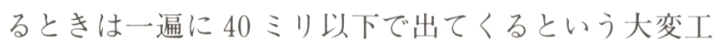

程を短縮する破砕機を開発した。この破砕機で 40 ミ リ角以下にし，次に定量供給機へ送る。

この定量供給機に入ると, 四の成型器はリング式の 装置であるが，順次定量供給して成型を行う。その後， 風送し, 冷却棟で空冷し, 製品ができ上がる。製品に 関しては当社は, 現在直径 8 ミリ長さ 10 ミリの粒状 ペレットを作っているがが，この成型器は，6ミリか ら 25 ミリ状のペレット状の燃料の成型が可能という ことで，いろいろなボイラーの機種に適合できる形状 の製品の生産が可能という形になっている。

なお, 定量供給機は, 現在, 時間当たり 3 トン半か ら 4 トンの定量供給ができ，また図中のマルチプレス 成型器は 2 トンの成型能力があり，ガサバル原料でも 1 トン $800 \mathrm{~kg} / \mathrm{H}$ ぐらいの成型加工できるという形で, 2 機で時間 4 トンの生産できる一連のラインを組んで やっている。

\section{3 生産における問題点}

私どもでは，現在，4機の製造プラントを 2 工場で 分けて設置し，先ほど申し上げたように月間 3,500 卜 ンの R.P.F.を 2 種類の形状で生産している。一つ は直径 40 ミリ，長さが 70 ミリの製品。もうひとつは 3 プラントで生産している直径 8 ミリ, 長さ 10 ミリ の粒状製品である。

まず直径 40 ミリ，長さ 70 ミリの燃料の方であるが, この棒状燃料は流動焼ボイラー専用燃料としして開発

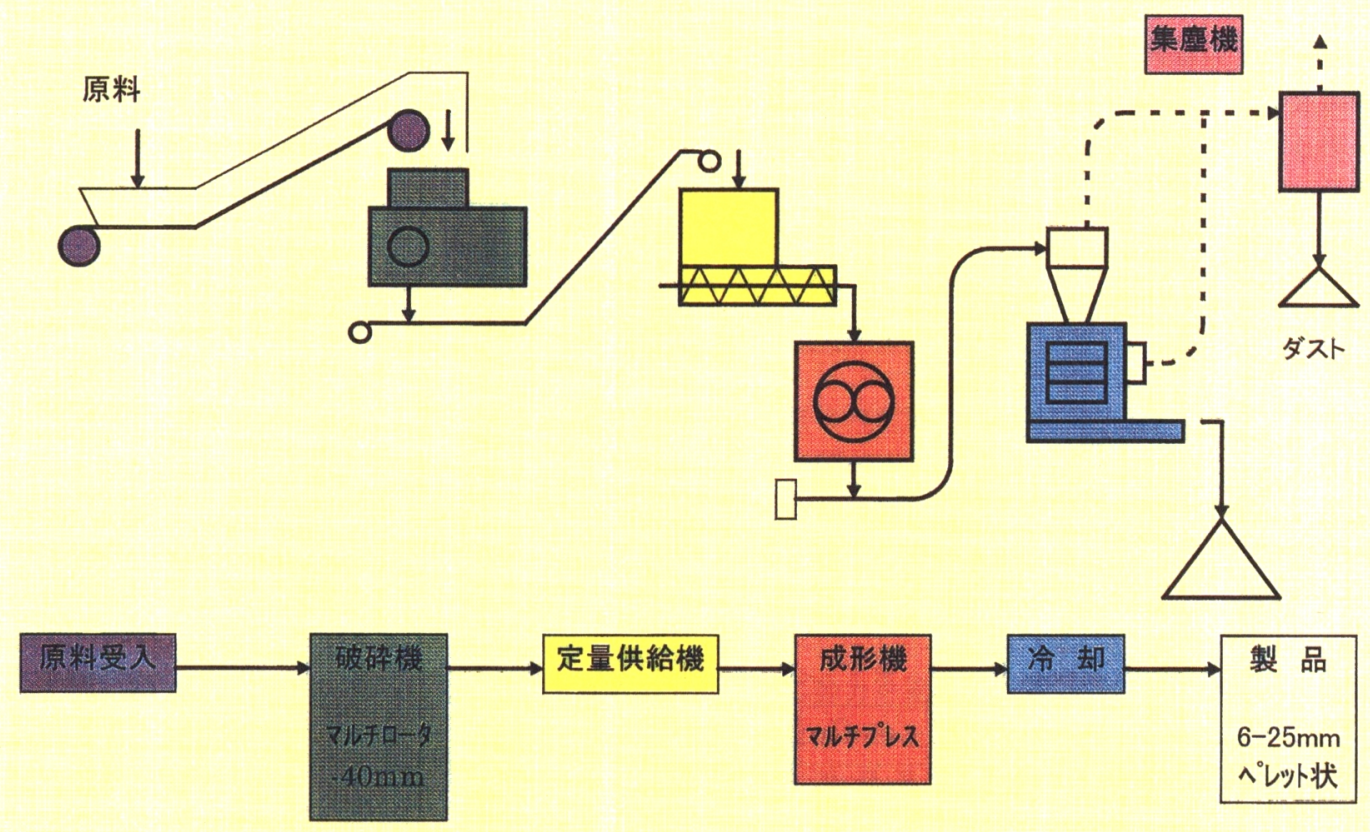

図 1 RPF 製造設備フロー 


四郎

したものなので，この長棒状の燃料に関しましては二 つの問題点があった。一つは大きい棒状燃料を燃すた めには専焼ボイラーを建設する必要があり，この流動 焼ボイラーは 1 基 12 億, 13 億というたいへん高価な もので，イニシャルコストが膨大になり，いろいろユ 一ザー先を探したのであるが，このバブル不況下なか なか，燃料転換をしてくれるというようなところは見 つからなかった。ユーザー探しに散々苦労して，1社 も見つからなかったという経験がある。もう一つの問 題はハンドリング面で，流動焼ボイラーでやるときの 搬送にどうしてもコンベアを使わなければない，エア 一搬送ができないという問題点である。微粉炭等ある いはチップ等のハンドリング制御のように上手くいか ないという難点があった。

この二つの難点をを解決するために，私どもは，2 基目から川崎重工製のマルチプレスを採用し，直径 8 ミリ，長さ 10 ミリという粒状の R.P.F.を製造する ことにした。この粒状の R.P.F.により，エアーの 搬送も可能になつた。また, バーナーによる吹き込み も可能となったので, 既設で使用する微粉炭やオイル コークス利用ボイラーにもちょっとした改造を施すだ けでR.P.Fの利用が可能になり，ユーザーの開拓が いっそう楽になった。そして，一段と弾みがついたと いう状況になった。現在私どもでは経験だけで申し上 げるのであるが，この方法が廃棄物燃料利用の上では 最も適しているのではないかというふうに判断してい る。

\subsection{R.P.F の品質}

先ほど申し上げたように, 形状は 8 ミリ，長さ 10
ミリとしているが，径の大きさは 6 ミリから 25 ミリ まで，ユーザーの希望に応じて変えることができる。 また，カロリーについても古紙，すなわち製紙原料に ならない古紙の混入率を変えることにより，6,000 キ ロカロリーから 8,000 キロカロリーまで対応ができる システムになっている。

表 1, 表 2 に通産省紙業印刷課で実施したR.P.F. の今後のあり方に関わる研究会で調べた分析結果表を 示す。原料の割合を四つに区別して分析したのがこの 表で，燃料として $\mathrm{N}$ 分， HCL 分， $\mathrm{S}$ 分は化石燃料に 負けない十分な品質を保持できるという自信の持てる 数値になっている。

\section{R.P.F の販売について}

\section{1 販売先の使用状況と対化石燃料比較評価}

次に R.P.F.の販売先の使用状況と化石燃料との 比較であるが，私どもでは現在蒸気生産用の流動焼ボ イラーに 6,000 キロカロリーの R.P.F.を供給し， また石灰焼成用には 9,000 カロリーの 8 ミリ径粒状 R.P.F.を供給している。またコークスガススロー に関しては，8,000 キロカロリーという熱量にて供給 している，価格・コスト面においては化石燃料の 3 分 の 1 から 4 分の 1 の価格で供給している。これにより, ユーザー各社では R.P.F. 使用前と比較いたしまし て平均 60\%から $70 \%$ の燃費のコストダウンが図られ ている。たいへんな額になるのであるが，60\%以上の 燃料のコストダウンができたという結果が出ており， にユーザーから大変喜ばれている。

また，ハンドリング面においても粒状化した後は化

表 1 紙, プラスチック類混合割合

\begin{tabular}{|c|c|c|c|c|c|c|}
\hline & & & & & (単位 & 量\%） \\
\hline & 項 & 目 & 試料 1 & 試料 2 & 試料 3 & 試料 4 \\
\hline & ラミネー1 & & 10 & 17 & 20 & 23 \\
\hline & 杂隹 & & 10 & 17 & 20 & 23 \\
\hline & 段 ボー & & 10 & 17 & 20 & 23 \\
\hline & 1 & 計 & 30 & 50 & 60 & 70 \\
\hline $7^{\circ}$ & $\mathrm{PE} \cdot \mathrm{PP} \cdot$ & 合物 & 23 & 17 & 13 & 10 \\
\hline x & カツラ ( & トトルの代用） & 23 & 17 & 13 & 10 \\
\hline \% & $\mathrm{PE}$ フィル & & 23 & 17 & 13 & 10 \\
\hline 類 & , & 計 & 70 & 50 & 40 & 30 \\
\hline & 合 & 計 & 100 & 100 & 100 & 100 \\
\hline
\end{tabular}


表 $2 \mathrm{RPF}$ 成分分析試験結果

\begin{tabular}{|c|c|c|c|c|c|c|c|}
\hline \multicolumn{2}{|c|}{ 項 目 } & 単 位 & 試料 1 & 試料 2 & 試料 3 & 試料 4 & 分析方法 \\
\hline \multirow{2}{*}{$\begin{array}{l}\text { 到着 } \\
\text { 基準 }\end{array}$} & カサ密度* & $\mathrm{g} / \mathrm{cm}^{3}$ & 0.363 & 0.390 & 0.432 & 0.451 & JIS K 2145 \\
\hline & 水 分 & $\%$ & 8.9 & 9.3 & 8.3 & 8.2 & \multirow{4}{*}{ JIS M 8812} \\
\hline \multirow{5}{*}{ 無 } & 灰 分 & $\%$ & 4.18 & 5.32 & 5.75 & 6.32 & \\
\hline & 揮 発 分 & $\%$ & 88.27 & 86.31 & 85.29 & 83.79 & \\
\hline & 固定炭素 & $\%$ & 7.55 & 8.37 & 8.96 & 9.89 & \\
\hline & 高位発熱量 & $\mathrm{kcal} / \mathrm{kg}$ & 7,180 & 6,770 & 6,260 & 6,120 & \multirow{2}{*}{ JIS M 8814} \\
\hline & 低位発熱量 & $\mathrm{kcal} / \mathrm{kg}$ & 6,730 & 6,290 & 5,852 & 5,680 & \\
\hline \multirow[t]{2}{*}{ 水 } & 炭素 & $\%$ & 65.14 & 63.60 & 57.96 & 56.17 & \multirow{6}{*}{ JIS K 8813} \\
\hline & 水 & $\%$ & 8.40 & 8.95 & 8.07 & 8.08 & \\
\hline \multirow[t]{2}{*}{ 基 } & 窒 & $\%$ & 0.74 & 0.44 & 0.32 & 0.11 & \\
\hline & 酸 & $\%$ & 21.40 & 21.42 & 27.59 & 29.08 & \\
\hline \multirow[t]{4}{*}{ 準 } & 燃焼性硫黄 & $\%$ & 0.00 & 0.05 & 0.08 & 0.04 & \\
\hline & 全 硫 黄 & $\%$ & 0.01 & 0.06 & 0.09 & 0.05 & \\
\hline & 燃焼性塩素 & $\%$ & 0.14 & 0.22 & 0.23 & 0.20 & \multirow{2}{*}{ JIS K 0101} \\
\hline & 全 塩 素 & $\%$ & 0.14 & 0.22 & 0.23 & 0.20 & \\
\hline \multicolumn{2}{|c|}{ 着火温度 } & ${ }^{\circ} \mathrm{C}$ & 396 & 376 & 391 & 385 & 燃料試験法 \\
\hline
\end{tabular}

*：圧力付加無し。

石燃料とほほ同等の評価が得られ, 現在, 再三供給の 増量をユーザーの方から要求されており，その要請に 応えるべく計画をいろいろ練っておるところある。

\subsection{R.P.F.の需要動向と将来性}

このR.P.F.の需要動向と将来性であるが，これ はにR.P.F.の利用サイドと原料サイドの二方面か ら見る必要がある。現在，紙パルプ業界では年間 390 万トンで, セメント業界では 1,000 万トン，また化学 では 155 万トンもの石炭を利用していると聞いている が, 今後 $\mathrm{CO}_{2}$ 問題の配慮等でこれらの化石燃料から の $\mathrm{CO}_{2}$ の発生を減少する対策としてこの R.P.F.へ に燃料代替が進むのではないかと期待している。

製紙業界では年間 60 万程度の R.P.F.の利用が可 能という見方もあるとお聞きしている。また，製鉄業 界の方では当社と試験的規模ではあるが利用を暫時進 めており，将来的にはかなりの利用が見込まれるので はないかと予測される。

また原料供給サイドの方から考ると，製紙や印刷業 界から排出される有価物として取り引きされていない 紙屑及び廃プラスチックが 92 万トン，また他産業か
ら排出されている産業廃棄物としての廃プラスチック が 440 万トンに上ると聞いているので, 原料供給にも 一切問題はないというふうに考える。今後 R.P.F. の利用はいろいろな壁を乗り越えながらも年を追うご とにその利用は加速されていくのではないかと期待し ている。

\section{R.P.F. の今後の課題}

\section{1 ユーザーの確保}

将来の見通しは明るいといっても，ユーザーの確保 は一朝一夕にできるものではない。まずR.P.F.と いうものを化石燃料を消費している業界に正しく理解 していただく必要がある。これには，やはり一業界の 声だけではなく，官民うち揃った広報活動，またユ一 ザー1 社 1 社に地道に説明して歩きながらの理解を深 める努力を重ねて, 初めて利用の促進が可能になるの ではないかと考える。

\subsection{R.P.F. 生産の法的問題点}

R.P.F.の生産にける法的問題は, 古紙・廃プラス チックのサーマルリサイクルをより活発に展開してい 
く，また推進して行くにあたり，最も問題になるのが 設備設置のための土地の設定及び取得である。次に， 廃菓物処理業許可の取得である。これらが最大の課題 である。昨今, 廃棄物処理場の設置に関して, 本当に 些細なことで住民の方が反対のための反对といった形 の反对連動が起こり易く，住民の同意がなかなか得ら れないという切実な問題が出て来ている。

\subsection{R.P.F. 設備設置における国の支援}

今まで説明したように，R.P.F. 事業は環境保全対 策やエネルギー対策から見ても実用的な即効的なりサ イクルシステムであると私は考えているが，これにま で産業廃衰物処理施設として「廃掃法」が適用され， 数多くの規制にしばられる。この規制を乗り越えなが ら，住比の同意書を一生懸命とりながら建設しようと いしても，一部住民の反対で計画が挫折するというも のも数多くある。許可の取得がたいへん困難であると いう状沉はまさに現実的問題である。

このために R.P.F. 製造事業を再生燃料製造事業 と公式に認定していただき，原料の収集，運搬，製造， そ机から製品の販売については「廃掃法」の適応除外 という形でL業団地等への速やかな進出が可能になる ような規制緩和が必要ではないかと私は考えている。

私どもは，昨年 12 月，新エネルギー利用等による 促進に関する特別措置法（新エネ法）に基づく認定計 幽第 1 号として事業認定を受けることができた。これ はダイオキシンの発生などの心配がないといった環境 への影響が小さい上に，現在に実用化が進んでいる R.D.F.よりも，新燃料としての効果が実用上大きい ということが認められたた妨思う。いままで，廃棄 物利用の燃料製造自体は，国の支援の対象にはなって いなかったが，この新エネ法により，ネドの債務保証 を受けら妃るとともに, 政府金融機関の融資優遇など, 資金調達の川滑化や資金コス卜の軽減が可能になって きている。このような支援が具体化しつつあるという ことを本当に嘉んでいるところである。

そういったことで，私どもの事業概況をお話申し上 げたが，私どもは，今後，この事業をよりいっそう力 強く推進し, 環境保全及び新エネルギーの確保に微力 ながら尽くしていきたいと思っている。

\section{5. 質疑応答と補足説明}

\subsection{R.P.F.の熱量}

製品の品質のなかのカロリーは, 廃プラスチック $100 \%$ R.P.Fでは大体 9,000 カロリー以上のもの が得られる。それにミックス古紙を $30 \%$ 程混ぜます と大体 6,800 から 7,300の間の熱量が得られるといj 結果が出ている。私ども一番今目標にしているのはミ ックス古紙と廃プラスチックの $50 ： 50$ の製品を販売 拡充である。6,000 カロリ一以上の熱量が得られると いうことで，石炭並みかそれ以上の熱源となりうる。 そのため, 50 ・50 製品を主力に販売したいと考えて いる。

その他，古紙を $60 \%$ まで混ぜると 5,800 カロリー ぐらい, $70 \%$ 混ぜても 5,500カロリーぐらいとなり, 石炭並みのカロリーは得られる。このように, 古紙及 び廃プラスチックの燃料化ということは, 完壁とは行 かなくての，まず良質の燃料ができると判断している。

\section{2 ガス化溶融炉と可燃ゴミのサーマル リサイクルの対比（質問）}

ガス化溶融炉は, 現在, 地方自治体でも話題に取り 上げられ，また採用しようという動きある。私の本日 の話しでは，少し時機が早いと思い，省略したが，何 と言っても建設コストが大変高いのが問題。私も実際 いろいろ回って，ガス化という声を聞くが，それより も, 可燃性ゴミは今後産業廃棄物から一般可燃ゴミま でR.P.F.化できる。。ガス化を進めるよりも，まず 可燃ゴミ等はR.P.F. 化を普及させた方がコス卜面 で安いという有利性から優先させるべきであると考え ている。

\section{3 燃料価格・微粉炭との比較（質問）}

私どもは産業廃棄物処理業の方もやっているので処 理料をいただいている。それゆえ，やはりリサイクル 進める分にはバージン物よりも安くなければ普及は進 まないと思っている。そこで，処理料をいただき，燃 料の方は石炭の 3 分の 1 , あるいは重油の 4 分の 1 か ら 5 分の 1 で販売している。コストの方は処理料の方 でまかなうことにしている。 